\title{
Tantangan Dan Peluang Pendidikan Tinggi Dalam Masa Dan Pasca Pandemi Covid-19
}

\author{
Budi Indrawati \\ Fakultas Ekonomi dan Bisnis; Universitas Bhayangkara Jakarta Raya; Jl. Raya Perjuangan, \\ Marga Mulya, Bekasi Utara, Jawa Barat 17121. Telp: 021-88955882, 889955883; e-mail: \\ budi.indrawati@dsn.ubharajaya.ac.id \\ * Korespondensi: e-mail: budi.indrawati@dsn.ubharajaya.ac.id
}

\begin{abstract}
As long as covid-19 vaccine has not been discovered, then teaching and learning activities will not run as before by face-to-face, but have changed by doing distance learning online, learning and work from home, social distancing and physical distancing. This has an impact on the emergence of changes in the implementation of the Tri Dharma Perguruan Tinggi activities, namely teaching and learning activities, research and community service, so that changes occur in the method of its implementation. The condition of the covid-19 pandemic is what creates threat and obstacles to be resolved and opportunity for college to be utilized. College opportunities to carry out technological transformation that began during the covid-19 pandemic. College opportunities have begun to open classes utilizing technology.
\end{abstract}

Keywords: College, Covid-19, Opportunities, Threat

\begin{abstract}
Abstrak
Selama belum ditemukannya vaksin covid-19, maka kegiatan belajar dan mengajar tidak akan berjalan seperti semula dengan cara melalui tatap muka, namun telah berubah dengan melakukan perkuliahan jarak jauh secara online, belajar dan bekerja dari rumah work from home dan social distancing serta physical distancing. Hal ini berdampak kepada timbulnya perubahan pada pelaksanaan kegiatan Tri Dharma Perguruan Tinggi yaitu kegiatan belajar mengajar, penelitian dan pengabdian kepada masyarakat, sehingga terjadi perubahan dalam metode pelaksanaannya. Kondisi adanya pandemik covid-19 inilah yang menimbulkan tantangan hambatan untuk diselesaikan dan peluang kesempatan untuk dimanfaatkan oleh pendidikan tinggi. Peluang pendidikan tinggi untuk melakukan transformasi teknologi yang dimulai di masa pandemi covid-19. Peluang pendidikan tinggi mulai membuka kelas-kelas yang memanfaatkan teknologi.
\end{abstract}

Kata kunci: Pendidikan Tinggi, Covid-19, Peluang, Tantangan

\section{Pendahuluan}

Virus corona atau novel Coronavirus (2019-nCoV) menyebar sangat cepat ke negaranegara di dunia, dan mulai merebak akhir Desember 2019 di Kota Wuhan, Provinsi Hubei, China. Virus Corona kemudian berkembang di enam puluh lima negara pada Februari 2020. Menurut WHO (World heald Organization) per Tanggal 2 Maret 2020, jumlah penderita yang terinfeksi Covid-19 mencapai 90.308, sedangkan di Indonesia ditemukan dua orang yang terinfeksi virus covid-19. (Yuliana, 2020)

Kementerian Keuangan setidaknya mencatat ada delapan dampak yang disebabkan oleh wabah virus tersebut. 1). sampai tanggal 11 April 2020 ada lebih dari 1,5 juta karyawan 
mengalami pemutusan hubungan kerja (PHK) dan dirumahkan. Di mana sebesar 1,2 juta pekerja berasal dari sektor formal, 265ribu dari sektor informal. 2). Purchasing Managers Index (PMI) Indonesia di bawah level 50 yakni hanya 45,3 pada Maret 2020. 3). lebih dari 12.703 penerbangan di lima belas bandara dibatalkan dari Bulan Januari sampai Bulan Februari 2020, dengan rincian penerbangan domestik sebanyak 11.680 dan penerbangan internasional sebanyak 1.023. 4). sekitar Rp 207 miliar kehilangan pendapatan dari sektor pelayanan udara, dengan sekitar Rp 48 miliar kehilangan oleh penerbangan dari China. 5). jumlah turis menurun hingga 6.800 per hari, khususnya turis dari China. 6). Perhimpunan Hotel dan Restoran Indonesia memperkirakan penurunan tingkat okupansi di sekitar 6.000 hotel di Indonesia dapat mencapai $50 \%$. Ini bisa mempengaruhi turunnya devisa pariwisata lebih dari setengah devisa tahun lalu. 7). impor Indonesia sepanjang Januari-Maret 2020 turun 3,7\% year to date (ytd). 8). inflasi pada Bulan Maret 2020 tercatat sebesar 2,96\% year on year (yoy) disumbang oleh kenaikan harga emas perhiasan serta beberapa harga pangan yang melonjak. Meski, terjadi deflasi pada komoditas aneka cabai dan tariff angkutan udara (Santoso, 2020).

Pandemi Covid-19 mengubah secara revolusioner pembelajaran yang diselenggarakan oleh kampus. Dalam waktu cepat, kampus dipaksa untuk melaksanakan pembelajaran daring. Ada sekitar $97 \%$ perguruan tinggi telah mengadopsi pembelajaran daring (Dirjen Dikti, 2020).

Pandemi Covid-19 ini telah mendisrupsi Tridharma Perguruan Tinggi. Dalam bidang pendidikan dan pengajaran, sebelum pandemi proses pembelajaran dilakukan dengan metode tatap muka secara langsung, saat ini telah dilakukan secara daring. Bahkan prosesi wisuda di PTN seperti UNS telah dilakukan secara daring (Aritonang, 2020).

Salah satu dampak dari pandemi Covid-19 adalah 1). penurunan perekonomian, dan menimbulkan PHK dan pengangguran hampir di semua sektor, hal ini berdampak kepada kemampuan sebagian mahasiswa aktif, seperti kemampuan dalam pembayaran Sumbangan Pembinaan Pendidikan (SPP), hingga sampai putus kuliah. 2). Dampak lain dari pandemi Covid-19, jika rutin terus-menerus menggunakan metode perkuliahan jarak jauh (online), maka ada keberatan dari sebagian mahasiswa, karena sebagian mahasiswa memiliki keterbatasan dalam biaya pulsa online. 3). Dampak lainnya adalah bagi mahasiswa yang sedang menyusun skripsi, akan mengalami kesulitan untuk melakukan riset lapangan, dan kesulitan melakukan bimbingan, sehingga mereka terhambat untuk lulus tepat waktu, dan kondisi ini juga bisa menambah jumlah mahasiswa yang drop out (DO). 4). Dampak Covid-19 lainnya, jika dalam beberapa tahun ke depan, belum ditemukan vaksin covid-19, maka kegiatan pendidikan dan pengajaran tidak akan berjalan seperti semula, namun akan tetap belajar dan bekerja dari rumah work from home dan social distancing, menjaga jarak (physical distancing). Hal ini berdampak kepada timbulnya perubahan pada metode pelaksanaan kegiatan Tri Dharma Perguruan Tinggi.

Data dari Asosiasi Perguruan Tinggi Swasta Indonesia (APTISI) menyebutkan lima puluh persen mahasiswa tidak sanggup membayar Sumbangan Pembinaan Pendidikan (SPP). 
Perguruan tinggi swasta (PTS) yang merasakan langsung adalah, perguruan tinggi yang memiliki jumlah mahasiswa kurang dari 2.500 orang. PTS kategori ini jumlahnya sangat signifikan sekitar $75 \%$ dari jumlah perguruan tinggi di Indonesia (Nurhidayat, 2020).

Dibalik adanya hambatan atau tantangan berat (threat) bagi pendidikan tinggi di masa dan pasca pandemi covid-19, pasti ada kesempatan atau peluang (opportunity), untuk munculkan solusi yang terbaik dalam menghadapi kenyataan pandemik covid-19, sepanjang mampu untuk menggunakan potensi kreatif dari sumber daya yang ada. (Wahab, 2020).

\section{Metode Penelitian}

Penulisan ini menggunakan jenis penelitian kualitatif deskriptif. Jenis penelitian deskriptif yang berdasarkan tujuan, yaitu bertujuan untuk memberikan deskriptif, gambaran mengenai fakta-fakta, sifat-sifat, serta hubungan antar fenomena yang diteliti, termasuk hubungan kegiatan-kegiatan, sikap-sikap, pandangan-pandangan, serta proses-proses yang sedang berlangsung dan pengaruh-pengaruh dari suatu fenomena, atau untuk menentukan frekuensi distribusi suatu gejala atau frekuensi adanya hubungan tertentu antara suatu gejala dengan gejala lain (Silaen, 2013).

Sedangkan data penelitian yang digunakan adalah data kualitatif. Penelitian yang didasarkan pada data kualitatif dikenal dengan peneltian kualitatif, dimana data kualitatif adalah data yang tidak berbentuk angka atau bilangan, sehingga hanya berbentuk pernyataan atau kalimat. (Suliyanto, 2018).

Tempat penelitian kepustakaan. Penelitian kepustakaan merupakan penelitian yang dilakukan dengan menggunakan bahan-bahan karya tulis atau bahan kepustakaan (literature) termasuk hasil-hasil penelitian sebelumnya. Penelitian ini biasanya digunakan untuk penelitian sejarah, dan pandangan atau pemikiran seorang tokoh. (Suliyanto, 2018).

\section{Hasil dan Pembahasan}

\subsection{Tantangan Pendidikan Tinggi Dalam Masa Pandemi Covid-19}

\section{a. Permintaan Terhadap Pendidikan Tinggi Berdampak Menurun}

Bagi perguruan tinggi, sebagai dampak dari banyaknya PHK, akan mempengaruhi penurunan sumber penghasilan keluarga, yang dapat mengurangi minat masyarakat untuk tidak melanjutkan atau menunda melanjutkan pendidikan ke jenjang yang lebih tinggi, berdampak berkurangnya jumlah mahasiswa baru.(Prodjo, 2020).

Bagi mahasiswa berdampak kepada kemampuan sebagian mahasiswa, seperti kemampuan dalam pembayaran Sumbangan Pembinaan Pendidikan (SPP),

\section{b. Metode Belajar Mengajar Berubah Cara Online}

Bagi perguruan tinggi, sebagian besar pendidikan tinggi melakukan perubahan dalam proses belajar mengajar yang semula tatap muka, berubah menjadi online. Bahkan semua perguruan tinggi telah dengan terpaksa melaksanakan perkuliahan online, yaitu opsi darurat yang telah berubah menjadi sistem utama dalam proses belajar mengajar. Hal ini berdampak kepada timbulnya perubahan pada pelaksanaan kegiatan Tri Dharma Perguruan Tinggi. 
Bagi mahasiswa Kesulitan untuk melakukan riset lapangan, dan kesulitan melakukan bimbingan, sehingga mereka terhambat untuk lulus tepat waktu, dan kondisi ini juga bisa menambah jumlah mahasiswa yang drop out (DO).

\section{c. Muncul Masalah Dalam Metode Cara Online}

Keterbatasan biaya pulsa internet. Bagi mahasiswa, sebagai dampak penghasilan keluarga yang berkurang, maka dengan metode online yang terus-menerus dalam belajar, maka biaya jaringan internet yang sangat dibutuhkan dalam pembelajaran daring menjadikan suatu hal yang memberatkan. kuota internet atau paket data yang dibeli untuk kebutuhan internet menjadi tinggi.

Civitas akademika belum terbiasa menggunakan cara online. Muncul kesulitan dalam menggunakan metode online, karena belum dilatih mengunakan system dan peralatannya. Sehingga perlu tambahan dukungan tutorial untuk menyesuaikan dengan model pembelajaran online.

Lemahnya kreativitas pengajar, Tidak semua dosen dan mahasiswa menguasai teknologi, dikarenakan penguasaan teknologi yang masih rendah.(Syah, 2020).

Keterbatasan sarana aplikasi dan peralatan belajar laptop atau smartphone.

Sebagian pengajar dan mahasiswa belum memiliki perangkat untuk memfasilitasi pembelajaran, misalnya handphone masih model jadul. Akibatnya, home learning menjadi dosen memberi tugas, lalu mahasiswa mengerjakan tugas.

Gangguan sinyal dalam kuliah online. Jaringan internet yang belum memadai di daerah tempat tinggal, terkadang tidak stabil, lemah, karena letak tempat tinggal yang masih jauh dari jangkauan sinyal seluler. Sehingga kegiatan belajar online tidak dapat berjalan dengan baik. Sehingga timbul kesenjangan perbedaan kecepatan internet diberbagai daerah. Orang-orang dipusat kota lebih menikmati internet yang jauh lebih cepat dibandingkan dengan mereka yang tinggal di daerah yang kurang berkembang.

Kejenuhan kuliah online dialami pengajar dan mahasiswa. Jika perkuliahan jarak jauh (PJJ) berlangsung dalam waktu yang lama terus-menerus, maka muncul kejenuhan dalam belajar online. Jika kejenuhan tersebut tidak segera diatasi, maka akan menyebabkan tidak optimalnya proses belajar-mengajar yang berujung pada hasil pembelajaran yang tidak memuaskan. Kuliah daring online memang tidak sesempurna perkuliahan di kelas secara langsung

\subsection{Peluang Pendidikan Tinggi Dalam Masa Pandemi Covid-19}

\section{a. Perguruan Tinggi Lebih Memanfaatkan Teknologi.}

Saat ini teknologi sudah berkembang luas, bisa melakukan penerimaan mahasiswa baru secara online, tes calon mahasiswa secara online, kurikulum baru berbasis digital, penerapan absensi online, pengelolaan akademik, pengelolaan SDM, hingga tracer study. Masa pandemi ini menjadi puncak penggunaan teknologi dalam pendidikan, dan ini bersamaan dengan era Revolusi Industri 4.0 yang terus maju, sehingga tantangan pandemi covid - $19 \mathrm{di}$ era revolusi industri 4.0 harus dapat dikelola menjadi peluang.

Implikasi Manajerial sebagai berikut: 
1) Dampak dari covid-19, adalah seluruh pendidikan tinggi akan telah terbiasa menggunakan IT (informatica technology), sehingga pemakaian IT meningkat dalam kegiatan belajar mengajar (KBM), kegiatan Tri Darma Perguruan Tinggi, serta dalam kegiatan administrasi akademik dan keuangan serta data-data pada bagian pusat komputer, sehingga peluang menjadikan kampus sebagai lembaga pendidikan tinggi berbasis IT yang lebih berkualitas.

2) Melalui penyediaan fasilitas sarana-prasarana IT yang berkualitas dan kuat seperti penyediaan wifi, web, elearning, dan pemberian subsidi mahasiswa dalam kuota pulsa online (jika terus-menerus pelaksanaan KBM jarak jauh diberlakukan), maka peluang memungkinkan kampus naik peringkat, sebagai akibat dari data -data kegiatan Tri Darma Perguruan Tinggi yang tercatat lengkap.

3) Pandemi covid-19 berdampak kepada penurunan perekonomian, timbul PHK dan pengangguran hampir di semua sektor, dan berdampak kepada jumlah mahasiswa yang mendaftar akan menurun. Timbul persaingan antar perguruan tinggi (PT) dalam menarik mahasiswa baru, sehingga peluang kampus untuk segera menerapkan kebijakan yang lebih strategis, dalam menyesuaikan dengan kondisi adanya pandemi.

4) Dengan munculnya pandemi covid-19, menjadikan perkuliahan online jarak jauh menjadi suatu kegiatan yang diakui oleh seluruh negara dimanapun di dunia, sehingga memungkinkan pendidikan tinggi dapat menerapkan perkuliahan jarak jauh seperti Universitas Terbuka. Hal ini menjadi peluang kampus dapat menyelenggarakan perkuliahan jarak jauh untuk menarik mahasiswa yang bertempat tinggal jauh dari kampus, dan berdampak meningkatkan jumlah mahasiswa baru.

5) Dengan diterapkannya perkuliahan jarak jauh (online) oleh seluruh kampus, memungkinkan peluang kampus untuk meningkatkan penerimaan mahasiswa melalui perkuliahan kelas karyawan secara online, karena mahasiswa karyawan / mahasiswa bekerja mempunyai waktu yang terbatas untuk berada di kampus.

\section{b. Mahasiswa dan Pengajar Dapat Mengatur Waktu Perkuliahan Lebih Fleksibel.}

Solusi dari kejenuhan terus menerus dari kuliah online, namun tetap tidak mengurangi waktu dan kegiatan perkuliahan yang seharusnya seperti ceramah, diskusi, dialog, tanya jawab, dan membuat kuis dan latihan. Diharapkan dapat menimbulkan sikap optimisme dari mahasiswa untuk lebih dalam mempelajari lagi materi yang sudah diberikan oleh pengajar. Sekaligus diharapkan juga dapat mempengaruhi kemandirian belajar mahasiswa (Firman, 2020).

\section{c. Peraturan Kemendikbud, Solusi Menghadapi Dampak Covid-19.}

Kemendikbud maupun Dirjen Dikti telah mengeluarkan peraturan yang terkait dampak covid-19 terhadap proses belajar mengajar di perguruan tinggi, diantaranya sebagai berikut:

1) Surat Mendikbud Nomor: 36962 / MPK.A / HK / 2020 tentang Pembelajaran secara Daring dan Bekerja dari Rumah dalam Rangka Pencegahan Penyebaran COVID-19.

2) Surat Edaran Dirjen Dikti Nomor: 302 / E.E2 / KR / 2020 Tentang Masa Belajar Penyelenggaraan Program Pendidikan. Menjelaskan sebagai berikut: 
a) Masa belajar paling lama bagi mahasiswa yang seharusnya berakhir pada semester genap 2019/2020, dapat diperpanjang 1 semester, dan pengaturannya diserahkan kepada Pimpinan Perguruan Tinggi sesuai dengan kondisi dan situasi setempat;

b) Praktikum laboratorium dan praktek lapangan dapat dijadwal ulang sesuai dengan status dan kondisi di daerah;

c) Penelitian tugas akhir selama masa darurat ini agar diatur baik metode maupun jadwalnya, disesuaikan dengan status dan kondisi setempat;

d) Periode penyelenggaraan kegiatan pembelajaran semester genap 2019/2020 pada seluruh jenjang program pendidikan agar dapat disesuaikan dengan kebutuhan masing-masing perguruan tinggi sehingga seluruh kegiatan akademik dapat terlaksana dengan baik;

e) Persiapan pelaksanaan langkah-langkah sebagaimana disampaikan dalam angka 1 sampai 4 di atas agar terlebih dahulu dikoordinasikan dengan Lembaga Layanan Pendidikan Tinggi setempat.

Perguruan Tinggi diharapkan dapat mengawasi dan membantu kelancaran pelaksanaaan pembelajaran dari rumah. Penghematan biaya operasional yang diperoleh selama pelaksanaan pembelajaran dari rumah (study from home), dapat dialihkan fungsi untuk subsidi pulsa koneksi dari pembelajaran daring, atau bantuan logistik dan kesehatan bagi mahasiswa yang membutuhkan.

3) Surat Edaran Dirjen Dikti Nomor: 331 / E.E2 / KM / 2020 Tentang Bantuan Sarana Pembelajaran Daring kepada Mahasiswa.

\subsection{Kebijakan dan Langkah Strategis Kampus Menghadapi Pandemi Covid-19.}

1) Sebagai solusi dari keterbatasan kemampuan sebagian mahasiswa dalam pembayaran Sumbangan Pembinaan Pendidikan (SPP) dan biaya pulsa internet. Dikti menghimbau agar perguruan tinggi dapat membantu mahasiswa, seperti memberikan subsidi pulsa koneksi pembelajaran daring, bantuan logistik dan kesehatan bagi yang membutuhkan(Dikti, 2020).

2) Sebagai solusi hambatan dalam bimbingan skripsi dan riset lapanga, sehingga mahasiswa menjadi terhambat untuk lulus tepat waktu, dan kondisi ini juga bisa menambah jumlah mahasiswa yang drop out (DO). Dikti menjelaskan bahwa masa belajar semester genap 2019/2020, dapat diperpanjang sampai satu semester, dan pengaturannya diserahkan kepada Pimpinan Perguruan Tinggi sesuai dengan kondisi dan situasi kampus (Dikti, 2020).

Maksud dari poin pertama dalam Surat Edaran Nomor : 302/E.E2/KR/2020 tersebut, adalah bahwa Dikti memberikan perlindungan kepada mahasiswa yang terancam drop out (DO), sebagai dampak dari terjadinya situasi darurat pandemi covid-19, yaitu dengan kebijakan pemberian perpanjangan masa belajar sampai satu semester.

3) Sebagai solusi kesulitan melakukan riset lapangan untuk penelitian tugas akhir. 
Dikti menjelaskan selama masa darurat agar diatur baik metode maupun jadwalnya, disesuaikan dengan status dan kondisi setempat (Dikti, 2020).

Surat edaran tersebut menjelaskan bahwa karya tulis akhir (skripsi) tidak harus berupa pengumpulan data primer di lapangan atau laboratorium. Metode dan waktunya bisa beragam dan fleksibel sesuai bimbingan dari dosen pembimbing. Dalam edaran ini juga menuntut perguruan tinggi untuk mengatur kembali jadwal dan metode ujian termasuk ujian skripsi dengan memperhatikan situasi dan kondisi di kampus.

Dalam Peraturan Pemerintah Nomor 60 tahun 1999 tentang Pendidikan Tinggi, pada Pasal 15 dijelaskan bahwa ujian dapat diselenggarakan melalui dua mekanisme, pertama ujian akhir program studi, dan kedua ujian skripsi. Dalam bidang bidang tertentu untuk program sarjana dapat dilaksanakan tanpa melalui mekanisme ujian skripsi. Jika menggunakan aturan ini jelas bahwa ujian skripsi bisa diganti dengan ujian lainnya, peraturan ini berlaku dalam kondisi dan situasi normal. Sehingga dapat disimpulkan bahwa dalam situasi dan kondisi normal saja ujian skripsi bisa digantikan dengan ujian lain. Tentu hal ini sangat diperbolehkan dalam situasi dan kondisi saat pandemi covid-19. Hal ini juga diperkuat Kemendikbud memperbolehkan ujian akhir di tingkat perguruan tinggi seperti skripsi, tanpa riset ke lapangan. Kebijakan ini diambil, guna memudahkan mahasiswa di tengah ancaman wabah virus corona (covid-19). Dalam penyusunan tugas akhir (skripsi), mahasiswa dapat menggunakan metode lain, seperti menggunakan kajian literature (Nurhidayat, 2020).

4) Sebagai solusi civitas akademika yang belum terbiasa menggunakan online. Masalah kurang inovatifnya pembelajaran yang disajikan para pendidik yang mendidik generasi $Z$, seharusnya dibekali berbagai pengetahuan dan ilmu baru yang relevan untuk generasi saat ini. Untuk itu sangat diperlukan peningkatan pelatihan bagi para SDM, agar SDM menjadi lebih update dan kreatif. Sehingga sebagian besar perguruan tinggi telah melakukan pelatihan menggunakan system online kepada pengajar selama pandemi.

\subsection{Kegiatan Pembelajaran dan Implementasi Merdeka Belajar di Masa Pandemi}

Merdeka Belajar di perguruan tinggi yang lebih otonom. Prinsipnya, perubahan paradigma pendidikan agar menjadi lebih otonom dengan kultur pembelajaran yang inovatif. Kebijakan Merdeka Belajar: Kampus Merdeka mendorong proses pembelajaran di perguruan tinggi yang semakin otonom dan fleksibel. Hal ini bertujuan demi terciptanya kultur belajar yang inovatif, tidak mengekang, dan sesuai dengan kebutuhan masing-masing perguruan tinggi (Nizam, 2020).

Konsep merdeka belajar adalah kemerdekaan unit pendidikan untuk melakukan inovasi. Oleh karena itu pengajar bersama mahasiswa dapat melakukan bersama dan membuat suatu inovasi dalam belajar. Yang tentunya disesuaikan dengan budaya, agama, sosio ekonomi dan kearifan lokal.

Dalam masa pandemi, kegiatan belajar mengajar otomatis menggunakan perkuliahan jarak jauh online, jika jenuh dengan kegiatan tanpa tatap muka ini, dapat melakukan tatap muka dengan zoom atau google meet atau sarana lainnya, serta bentuk variasi dalam pemberian soal 
dan pertanyaan, dan dengan lebih banyak memberikan contoh- contohdan latihan, terutama contoh sederhana. Dalam masa pandemi, kegiatan inovasi belajar memang sangat tergantung kepada teknologi, oleh karenanya pengajar maupun mahasiswa harus update dalam teknologi.

\subsection{Terobosan Riset dan Inovasi yang Dihasilkan}

Riset yang dilakukan dapat lebih banyak menggunakan analisa kuantitatif dengan data sekunder yang dapat diperoleh dari Badan Pusat Statistik (BPS), Bursa Efek Indonesia (BEI), perpustakaan-perpustakaan online dan sumber data lainnya. Sedangkan riset dengan analisa kualitatif jika terpaksa harus dengan kuesioner, sebaiknya menggunakan google form. Penelitian hendaknya yang berkaitan dengan peningkatan kesejahteraan masyarakat luas, seperti masalah bagaimana produksi usaha mikro kecil menengah (UMKM) yang lebih efisien, masalah peningkatan penghasilan masyarakat, masalah penggunaan sumber-sumber pangan lokal dan ekonomi kreatif.

Inovasi yang dilakukan diantaranya seperti membuka usaha UMKM yang terkait dengan produk-produk yang paling banyak dibutuhkan oleh masyarakat selama masa pandemi covid19, seperti produk-produk kesehatan : APD (alat pelindung diri), masker kain, hand sanitizer, desinfektan, dan produk-produk sembilan bahan kebutuhan pokok (sembako) dengan sistem penjualan pemasaran online. Mengaktifkan kembali pemanfaatan halaman pekarangan rumah menjadi kebun dan apotik hidup, serta sosialisasi tanaman hidroponik atau aquaponik.

\subsection{Pengabdian Kepada Masyarakat, Bergotong Royong Mengatasi Masalah}

Permasalahan masyarakat dalam masa pandemi covid-19 umumnya adalah masalah penurunan ekonomi, yang berdampak kekurangan kebutuhan pangan atau sembako. Sebaiknya kegiatan pengabdian kepada masyarakat diarahkan kepada kepedulian terhadap masyarakat yang mengalami dampak tersebut. Secara bersama-sama membantu bagi yang mampu dengan menyisihkan sebagian penghasilan atau pemberian sembako kepada yang membutuhkan, dengan melibatkan civitas academika dan alumni yang lebih luas. Jadi lebih kepada kegiatan bakti sosial dan santunan (bansos).

\subsection{Pembelajaran yang Diperoleh dan Harapan Ke Depan}

Mencatat berbagai kekurangan di masa pandemi, untuk menyusun strategi pendidikan yang berorientasi pada kemajuan dalam jangka panjang. Di mulai dari kualitas pengajar, kelengkapan sarana-prasarana di setiap unit pendidikan, ketersediaan fasilitas jaringan internet, sampai persoalan bantuan untuk para mahasiswa yang kurang. Kehidupan pasca-pandemi Covid-19 tentu tidak akan sama seperti kehidupan seperti sebelumnya. Akan ada kebiasaan baru yang menjadi budaya dalam kehidupan masyarakat nantinya. Mulai dari kebiasaan menjalani pola hidup bersih, lebih melek teknologi, dan lebih fleksibel dalam proses pembelajaran (Susanto, 2020).

Hikmah positif yang bisa diambil dari pandemi, antara lain adaptasi penggunaan teknologi dalam pembelajaran dengan sangat cepat. Adanya pandemi juga mendorong tumbuhnya energi kreatif dan positif yang sangat luar biasa besar. Dengan semangat 
gotong-royong dan kerja sama antar perguruan tinggi untuk saling meringankan beban selama pandemi harus dijaga dan dipertahankan pasca pandemi covid-19 (Nizam, 2020).

Dari analisa tantangan dan peluang pendidikan tinggi dalam masa pandemic covid-19 di atas, diharapkan dapat menjadi bahan evaluasi tentang efektivitas perkuliahan jarak jauh online, sehingga akan mendapatkan formula yang tepat untuk capaian kualitas pembelajaran yang diinginkan di masa pandemi covid-19.

\section{Kesimpulan}

Tantangan yang dihadapi pendidikan tinggi di masa pandemi covid-19, dihadapi dengan penerapan perkuliahan jarak jauh online, hal ini menunjukan pemanfaatan teknologi yang semakin meningkat sekarang dan diharapkan lagi nanti di masa yang akan datang. Untuk itu peluang bagi pendidikan tinggi dalam masa dan pasca pandemi sebagai berikut: a). Peluang kampus sebagai perguruan tinggi berbasis IT yang lebih berkualitas. Dampak dari penerapan teknologi dalam Tri Darma Perguruan Tinggi, dalam kegiatan administrasi akademik - keuangan serta data-data di pusat komputer. b). Peluang memungkinkan kampus naik peringkat, sebagai akibat dari data -data kegiatan Tri Darma Perguruan Tinggi yang tercatat lengkap. c). Peluang kampus untuk segera mengambil kebijakan yang lebih strategis, dalam menyesuaikan dengan kondisi riel pandemi covid-19. d). Peluang kampus untuk dapat menyelenggarakan perkuliahan jarak jauh untuk menarik mahasiswa yang bertempat tinggal jauh dari kampus. Sebagai dampak dari perkuliahan online menjadi suatu kegiatan yang diakui oleh seluruh negara di dunia, e). Peluang kampus untuk meningkatkan penerimaan mahasiswa melalui perkuliahan kelas karyawan secara online. karena mahasiswa karyawan memiliki waktu yang terbatas untuk berada di kampus.

\section{Daftar Pustaka}

Aritonang, A. Y. (2020). Antisipasi Pandemi Covid-19, Tak Perlu Kurikulum Baru Pendidikan Tinggi,. https://waspada.id/nusantara/antisipasi-pandemi-covid-19-tak-perlu-kurikulumbaru-pendidikan-tinggi/

Dikti, D. (2020). Surat Dirjen Dikti Nomor: 302/E.E2/KR/2020 Tentang Masa Belajar Penyelenggaraan Program Pendidikan.

Firman. (2020). Dampak Covid-19 terhadap Pembelajaran di. BIOMA, Program Studi Pendidikan Biologi Universitas Sulawesi Barat, Vol.2. No., 14-20.

Nizam, P. D. D. (2020). Menakar Pendidikan Pasca Pandemi COVID-19. http://www.dikti.go.id/highlight/menakar-pendidikan-pasca-pandemi-covid19/?utm_source= feedburner\&utm_medium=feed\&utm_campaign=Feed\%3A+go\%2Fdikti+\%28Direktorat+Je nderal+Pendidikan+Tinggi\%29

Nurhidayat. (2020). Problematika Pendidikan Tinggi Di Tengah Pandemi Covid-19 (Refleksi Hari Pendidikan). https://carapandang.com/read-news/problematika-pendidikan-tinggi-di- 
tengah-pandemi-covid19-refleksi-hari-pendidikan

Prodjo, W. A. (2020). Wabah Corona, Penerimaan Mahasiswa Baru di Sejumlah Kampus Swasta Menurun. Kompas.Com. https://www.kompas.com/edu/read/2020/04/17/070000171/wabah-corona-penerimaanmahasiswa-baru-di-sejumlah-kampus-swasta-menurun

Santoso, Y. I. (2020). Ini delapan dampak negatif bagi perekonomian Indonesia akibat wabah virus corona. Kontan.Co.ld. https://nasional.kontan.co.id/news/ini-delapan-dampaknegatif-bagi-perekonomian-indonesia-akibat-wabah-virus-corona

Silaen, S. dan W. (2013). Metodologi Penelitian Sosial Untuk Penulisan Skripsi dan Tesis. In Media, Jakarta.

Suliyanto. (2018). Metode Penelitian Bisnis untuk Skripsi, Tesis, \& Disertasi. Andi, Yogjakarta.

Susanto, A. (2020). Dilema Perguruan Tinggi di Tengah Pandemi Covid-19. http://pundi.or.id/2020/04/24/pendidikan-pasca-covid-19-pr-bagi-pemangku-kebijakan/

Syah, R. H. (2020). Dampak Covid-19 pada Pendidikan di Indonesia: Sekolah, Keterampilan, dan Proses Pembelajaran. SALAM: Jurnal Sosial Dan Budaya Syar-I, Vol.7, No., pp.295402. https://doi.org/10.15408/sjsbs.v7i5.15314

Wahab, R. (2020). Tantangan dan Kesempatan Pendidikan Era Covid-19. https://arbaswedan.id/tantangan-dan-kesempatan-pendidikan-era-covid-19/

Yuliana. (2020). Corona virus diseases (Covid -19); Sebuah tinjauan literatur. Wellness and Healthy Magazine, FK Universitas Lampung, Vol. 2, No, p.187-192. 